\title{
"History" as a Category in Contemporary Spiritual Theology
}

\author{
STANISŁAW T. ZARZYCKI
}

The John Paul II Catholic University of Lublin

zastan@wp.pl, ORCID: 0000-0002-1566-6695

\begin{abstract}
This article aims to explore and justify the usefulness of the category "history" as used in spiritual theology. Following an introduction to the main subject, the initial section shows the importance and usefulness of this category in contemporary theology, as dealt with by the theology of history. In the main section, the article discusses four fields in which the category of "history" lends its functionality to spiritual theology: biblical spirituality, liturgical spirituality, worldly commitment, and spiritual development. This section also explains how the category of "history" is operative in each of these fields. The last section of the article is a synthetic outline of the results of the research.
\end{abstract}

Keywords: spiritual theology, history, Bible, liturgy, worldly commitment, spiritual growth

Hans Urs von Balthasar proposed a novel approach to theology which had "stuck fast on the sandbanks of rationalist abstractions," with the intention to "get it moving again."' To do so, he outlined theology as a reflection of the drama of salvation realised between God and man in the history of the world. In order to show the essence of this dramatic setting and to urge contemporary man, unable to escape the dramatic events of his own life, to give a personal answer to Jesus Christ as a co-actor of the same drama, the Swiss theologian employed the "language of theatre." This included typically "dramatic categories" such as "decision," "choice," "act," "play" and "role." This dramatic set-up is intended to put man into motion and to turn him into an active participant in the "drama" of salvation history.

The usefulness and validity of the categories employed in Theo-Drama give rise to a question about the usefulness of these constitutive categories for Christian spiritual theology, which is regarded as harmonious with theology per se. ${ }^{3}$ The present study is confined exclusively to the category of "history," and it aims to determine

The article is a part of the project funded by the Ministry of Science and Higher Education, Republic of Poland, "Regional Initiative of Excellence" in 2019-2022; project number: 028/RID/2018/19.

Balthasar, Theo-Drama, 21.

2 Balthasar, Theo-Drama, 21-39.

3 Balthasar, Retour au centre, 36. 
its usefulness and functionality in spiritual theology. A prerequisite for this attempt is the need to justify, even briefly, the usefulness of the category of "history" in contemporary theology, where some theologians define it in terms of the theology of history. Its concept will be explained in both of these contexts. Thus, the main research question posed here is that of the role of the category of "history" in spiritual theology, and about the instrumentality of this category in specific fields of research in spiritual theology. Therefore, this article analyses the role of the category of "history" in selected areas of research within the discipline. The results of this analysis, with conclusions concerning the usefulness of the title category for explorations in spiritual theology, are outlined synthetically in the final paragraph.

\section{The Relationship between Spiritual Theology and the Theology of History - the Category "History"}

To demonstrate the relationship between the category of "history" and spiritual theology, it is necessary to begin with a clarification of the concepts referring to two different disciplines, and to explain what the theology of history is. Spiritual theology is understood to mean a scientific reflection on the spiritual life as life in the Holy Spirit (Rom 8:9; 8:4); on its development in the human soul and in the community of the Church; on its development as interpreted in the light of the Judeo-Christian revelation in order to expound on certain structures and principles of this experience; and on its development aimed at the communion between God and man. This discipline is systematic in nature due to it links to dogmatic theology. Yet, at the same time, it is applied in character, as it is connected with moral and pastoral theology, as well as with other more pragmatically-oriented areas of theology. In this way, spiritual theology contributes to the unity of theological studies. Thanks to this unity, theology as a whole, in conjunction with other auxiliary disciplines, better serves "guiding man towards the profound knowledge of the mystery of Christ, in order to proclaim it more effectively to God's people and to all peoples." ${ }^{4}$ For this reason, the Decree on Priestly Formation by the Second Vatican Council instructs us to renew the theological teachings "through a more living contact with the mystery of Christ and the history of salvation" (OT 16). The latest Ratio fundamentalis institutionis sacerdotalis also insists that students of theology "should learn how to penetrate more deeply into the mysteries of salvation and to grasp the connection between them by speculative investigation"s to be able to interpret life situations in the light of God's revelation and to respond to them.

John Paul II, Sapientia Christiana, 17.

Congregation for the Clergy, The Gift of the Priestly Vocation, 168. 
Contemporary theology reaches further than the eternal, unchangeable truths of faith, and perceives them in an anthropological and existential context, in the changing circumstances of human reality, ${ }^{6}$ in order to illuminate the way for man to realise his supernatural vocation. Christian perfection does not consist of pursuing an unchangeable course of action, but of an attitude that corresponds to the mentality of the epoch. ${ }^{7}$ For example, it requires taking into account the "signs of the times" in order to draw theological and practical from them. This is the meeting point of theology and history, in which the Christian faith is rooted as a response to the historical revelation of God in Jesus Christ. When history emerged as a science (the 18th-19th centuries), with its striving to understand things and events through their causes and conditions (environment, time), ${ }^{8}$ and historicity grew to become a dimension of the holistically-understood human life, theology began to rediscover its own historical dimension. Historicity became a conceptual category and an existential dimension of the human condition. This is true not only from the transitory perspective, but also in the sense of the gaining of the awareness of becoming a human being in the holistically-understood reality, accompanied by the axiological experience of man becoming oneself and humanity becoming itself.9

It was then that the scientific theology of history began - a discipline aimed at reading history in the light of faith. The term "theology of history" was introduced by Johann G. Droysen in 1843, but it was not until the early 20th century that the term found its wider application. ${ }^{10}$ Historical thinking in theology first manifested itself among Protestant theologians (David F. Strauss, Martin Kähler, Rudolf Bultmann, Martin Dibelius and Willi Marxsen) and then among the Catholic theologians of the Tübingen school (Johann S. Drey - the founder of the school, Karl J. Hefele, Johann G. Herbst, Johann B. Hirscher, Johann E. Kuhn, Johann A. Möhler, and Franz A. Staudenmaier). They were advocates of a critical analysis of the historical nature of revelation and promoted the seeking of coherence between truth and history. On the other hand, the representatives of the French school of Le Saulchoir - Ambroise Gardeil and Marie-Dominique Chenu - highlighted the importance of the primary status of revelation in theology and of the historical status of Christianity, as rooted in the mystery of the Incarnation. Hence, they postulated the departure of theology from the scholastic methodology, which was dominated by philosophical inclinations, in favour of the method of "discerning and reading theological sites" in actu, reading the "signs of the times," which linked theology with mysticism. ${ }^{11}$ The nouvelle théologie, that takes into account the historical dimension of revelation and faith, was

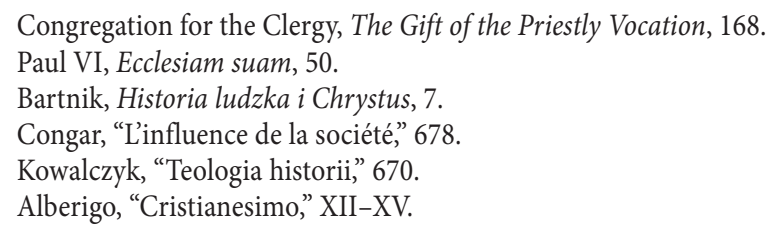


developed in the pre-Council period by such theologians as von Balthasar, Yves Congar, Jean Danielou, Henri de Lubac, Karl Rahner, Edward Schillebeeckx, or Gustave Thils. The ideas promoted by these theologians influenced the thinking of the Fathers at the Second Vatican Council and prevailed over the type of neo-scholastic theology represented by the Roman School, which was oriented towards defending the Catholic doctrine against liberalism and modernism. This prevalence manifests itself in two crucial Council documents: the Dogmatic Constitution on Divine Revelation Dei Verbum and the Pastoral Constitution on the Church in the Modern World Gaudium et Spes.

According to Czesław S. Bartnik, the notion of history has two meanings: 1) the subject-related meaning, which covers: a) knowledge inferred from observing and exploring events, people and things, and b) science researching the human past in a specific time and space (since the 19th century); and 2) the object-related meaning, which covers: a) knowledge inferred from observing facts, and b) "events," i.e. things that happen in a specific time and space, and human actions. ${ }^{12}$ The purpose and meaning of history (as a study and as the entirety of events) has often been subject to philosophical investigations (Hegel), with the highest momentum in the 19th century onwards, i.e. from the time of the historical crisis. While providing valuable criteria for the historical theory of cognition, its critical, reason-based, methods failed to discover the sense of history as revealed in Revelation. This is why the theology of history is necessary. It is

that part of theological knowledge which studies and formulates in the manner of theological sciences the whole of human individual and social action (or: the realisation of the human being at the existential level), as well as other dimensions (the cosmos, nature), in so far as they are associated with the former, in relation to the supernatural world, in the light of the revealed data and natural cognition. ${ }^{13}$

The Lublin theologian places in the mainstream of history the human being who is the basis of the community of people and the axiological (truth, good, beauty) and spiritual dimensions which are appropriate to them. He believes that with the ontological and personal understanding of history, history is not limited only to the temporal past, as in university disciplines, but also includes the present and the future,

12 Bartnik, Historia ludzka i Chrystus, 7-8. The Polish notion of "dzieje" (historical facts and events) dates back to $€$. Górnicki (16th century) and corresponds to the German concept Geschichte (in contrast to Historie - the objective documenting of past events and their research). Geschichte signifies the "political, cultural and social course of the developmental process in a given geographical or cultural sphere," also including the particular events that are constitutive of it; DUDEN Deutsches Universalwörterbuch, 485.

13 Bartnik, Teologia historii, 44. 
that is, all time and all reality in terms of its realisation and in relation to man." ${ }^{14}$ He understands Christ not only as the Redeemer and Saviour of man, but also as a "micro-history" with a universal dimension and relationship to all people, thanks to which the history of everyone can obtain in Him its Model, Centre, Norm, Key, Meaning and Ultimate Goal. ${ }^{15}$

The theology of history does not focus on a specific research problem and therefore is not a new, auxiliary discipline, but "is the centre for all speculative and historical theology." ${ }^{16}$ According to von Balthasar, historicity can be considered the key direction of today's theological inquiry. ${ }^{17}$ Such an orientation adopted by the theology of history is justified by the fact that it accentuates the Incarnation as a central Event in both human and salvation history. By recalling this Event and referring to its past, present and future history, and by presenting it as the dynamic process of salvation (or lack of salvation), the theology of history fulfils its historical and theological mission. The theology of history interprets, in the light of Revelation, the supernatural, divine sense of the world in its entirety (cultures, civilisations, religions, peoples and nations) in both the historical and developmental aspect. ${ }^{18}$

According to Bartnik, the research subject of the theology of history can be best formulated from a formal point of view as a vision of human existence in its relationship with God (historia sacra), as well as a vision of the history of creation (historia creata) - a proposal that manifests itself, among others, in the theology of history by von Balthasar, Thils and Pierre Teilhard de Chardin. ${ }^{19}$ Due to the fact that historico-theological disciplines do not belong to theology sensu stricto, it is difficult to connect them with theology and to establish both a historical and theological type of research methodology that would be appropriate for them..$^{20}$ Hence, the theology of history should rely on contemporary historical hermeneutics and be suited to the study, understanding and explanation of historically changing realities. ${ }^{21}$ Historical theology needs methods that can address its complexity and can be synergised in "grasping the sense of human existence throughout its history." Bartnik argues that the "humanistic" method meets these requirements. He also speaks of the need to use the "general theological method," due to the fact that

14 Bartnik, Historia ludzka i Chrystus, 11.

15 Bartnik, Historia ludzka i Chrystus, 320-321.

16 Góźdź, Jezus. Twórca i Spetniciel naszej wiary, 304.

17 Balthasar, Theo-Drama, 23.

18 Bartnik, Teologia historii, 41.

19 Bartnik, Teologia historii, 44. The earlier approaches adopted a dogmatic teaching on Divine Providence, based on revelation and the knowledge of the salvific plans of Providence specified therein. These findings were then juxtaposed against human history in order to find traces of Divine action in past events. Moreover, it also referred to the teaching about the "essence and fixed characteristics of Divine action in human history" in order to determine certain "regularities" behind historical events.

20 Bartnik, "Myślenie historyczne w teologii," 91.

21 Macheta, "Teologia historyczna," 267. 
the dynamic aspect of the studied reality is in harmony with its static aspect. ${ }^{22}$ As a possible complement to this method, Bartnik considers "cognition through symbols, theological analogies, or intuition subjected to conceptualisation, inspired by the Holy Spirit." ${ }^{23}$ The historical method, on the other hand, is only of an auxiliary functionality, employed at the earlier stages of research, e.g. for providing the theology of history with research material and for confronting and verifying certain preliminary theses.

It seems that the above-mentioned method of practising the theology of history matches the functional requirements of spiritual theology. Hence, the latter can use the method of the former to comprehend and explain the category of "history" employed within its framework. Thus, what does the category of "history" mean to spiritual theology? It should be noted that this sense of "history" does not correspond directly to the history of spirituality, that is, a retrospective branch of spiritual theology. The history of spirituality is highly necessary and useful, and not only for a theologian of spirituality. It helps us understand facts, matters, events and problems that happened in the past, and which may shed light on things that are happening today. It provides systematic spiritual theology with many critically verified documents from the past and arguments that the discipline should take into account. Therefore, all historical syntheses are more than valuable, both those more universal ones that have emerged since the 1920s as well as those that refer to specific periods in the history of spirituality. ${ }^{24}$

A category is what can be reasonably proposed about the elements of some single field of cognition, and what is radically different from the elements of another field of cognition. When the category of "history" is used in spiritual theology, it should be understood as a set of elements taken from history - not in the retrospective sense, but in the sense of the personal and social history of salvation and of natural historical events - which allow us to study the subject matter of spiritual theology as part of those events that may become salvific history taking place in the Church era. This category does not stop in the past, but concerns the present and the future in terms of the realisation of spiritual life, of holiness, by the Christian and the Church community. This is also how it differs from history as it is usually understood and the usual historical dimension, the dimension of past facts, events, and states of affairs that can be discovered in any scientific discipline.

Bartnik, Teologia historii, 79.

Bartnik, Teologia historii, 78-79.

Matanić, La spiritualità come scienza, 141-170; Secondin, "Nozione di spiritualità," 192-205. 


\section{Scopes of Functionality of the Category of "History" in Spiritual Theology and Its Specific Use}

The issue of the category of "history" is connected not only with the theological disciplines underlying spiritual theology, but also with its auxiliary sciences, including history, and with their potential contribution to spiritual theology. The term "theology of history," as noted above, is not unambiguous because, strictly speaking, the term "theology" refers to God, rather than to the created world and its history. As has been explained, the term "history" is understood here in the sense of the ongoing individual and social history, which in Christ becomes salvation history. In a broader sense, however, emphasised by the so-called anthropological turn in theology, the term "theology" refers not only to man in his intrinsic relationship with God but to all human life with all its temporal dimensions and ends, which, when subordinated to the will of God the Creator and Saviour, are directed towards a single, transcendent goal. The second issue is that the term "theology of history" was, from the very beginning, linked not to all theology, but only to fundamental and dogmatic theology, since these disciplines dealt primarily with Revelation and its historical aspect. This raises the question: can we speak of any relationship between spiritual theology and the theology of history?

It should be noted here that theology is not only about the message of Revelation addressed to the Church and to the individual faithful, but also about an adequate response to it. If the divine Revelation coming in Jesus Christ had not been answered by the apostles, disciples, etc., it would have remained God's monologue, and therefore would be an incomplete act. ${ }^{25}$ Spiritual theology is situated closer to the response of faith to divine Revelation and, because of the significance of this response, it is also closely linked to salvation history and to the theology of history. The latter researches salvation history in terms of the process that takes place in the history of the world. Spiritual theology draws upon Biblical studies, fundamental theology, dogmatic theology and moral theology. It examines its subject matter using auxiliary sciences, such as religious studies, patrology (patristics), liturgics, hagiography, psychology, pastoral theology, the pedagogy of religion, the sociology of religion and others. As has been already noted, history occupies an important position among the auxiliary sciences for spiritual theology, providing it with retrospective knowledge. Nonetheless, researchers dealing with history do not narrow the focus of their study to historical events as part of the historical process. ${ }^{26}$

Each of the auxiliary sciences is useful for exploring and explaining the subject matter of spiritual theology. Therefore, they can all add valuable elements which are helpful in the explication of the material and sometimes, too, of the formal research

25 Papieska Rada ds. Krzewienia Nowej Ewangelizacji, Żyć Rokiem Wiary, 30.

26 Matanić, La spiritualità come scienza, 119-122. 
subject. This is why various categories in psychology, sociology, etc. are postulated. History seems to be an extension of anthropology, but understood more broadly and approached from a dynamic and a developmental perspective. In what fields of spiritual theology can the category "history" be helpful? This article briefly outlines four such "sites."

\section{1. "History" as a Category in Biblical Spirituality}

Biblical history is not understood as a science of the past, which is concerned with the accuracy of the analysis of historical facts. Although the past is not without significance for it, Biblical historical analysis is concerned much more with the present history of the chosen people, bound to God by the covenant, as well as with the future of this people dependent on God. ${ }^{27}$ This type of history is shaped by the Word of God, revealing to the messenger of God - the prophet - and to the people of Israel God's plans and promises, which outline the path towards the salvific future. The Word of God (dabar) has been effective since the creation of the world and man (Heb 4:12), and preserves its power throughout the history of salvation. In its course, God's various interventions take place and various events are a direct or indirect result of these interventions. These events, together with the accompanying words explaining their meaning, complement each other and form a single divine revelation (DV 2) unfolding in the various stages of Israel's history. This interconnection between actions and words is most evident in Jesus Christ. He is a mediator between God and men, and His act is not only revelatory, but also salvific in its fullness (Matt 26:18, John 13:1). For Jesus is the ultimate Word that reveals God the Father, His designs, His goodness and His love for people. At the same time, Jesus is the Saviour who frees man from sin and grants him the Holy Spirit. Through this Spirit, the word of God remains alive and active in the hearts of the faithful. The Word guides them throughout salvation history towards the full knowledge of the truth in Christ (John 16:13) and to the ever greater freedom of the sons of God (Rom 8:15).

Biblical spirituality is about entering into a personal relationship with Jesus Christ through faith and through His word, which shows the will of God and leads to the participation in the sacraments of the Church. Drawing upon the results of research in contemporary exegesis and biblical theology, one could argue that this spirituality shows a model experience of faith and exhibits criteria for the interpretation and evaluation of a contemporary experience of faith, both communal and individual. According to biblical hermeneutics, the New Testament is foreshadowed by the Old Testament, while the Old Testament finds its explanation in the New Testament (DV 16).

Moulins-Beaufort, Exégese spirituelle et historie, 93. 
Contemporary spiritual theology pinpoints an insufficiency of approaches to spiritual life contained in treatises based on the statically-constructed scholastic anthropology. Instead, it seeks to anchor the foundations of spiritual life (e.g. theological virtues) and its various manifestations in the Bible in a new, more existential perspective. Spiritual theology brings closer and characterises those attitudes adopted by Christ as the fundamental structures of spiritual life, ${ }^{28}$ as well as those adopted by the Apostles, the disciples of the Lord. Old theological-spiritual treatises had little reference to the Bible and did not take into account, for example, the attitude of faith displayed by Jesus Christ. ${ }^{29}$ Although His faith must be understood differently from the attitude of faith of a disciple of Christ - the former being the faith of Jesus Christ as the Son of God - it cannot be ignored as a moral norm and as an example to follow (e.g. the trial of Jesus' faith at the Mount of Olives). The truth about Jesus Christ and His relationship to God the Father and to people must take into account His earthly history, His words and actions. It should also take into account His divine identity as revealed in signs, miracles etc. These signs prove that from the very beginning the figure of Jesus Christ exceeded the confines of a historical category. ${ }^{30}$ If, in his response to the historical revelations of God, man - through faith - accepts the Word of God and its message, he expects the realisation of God's promises in supernatural hope, and subordinates his temporal hopes to them. In love, he obediently wishes to carry out God's will for himself and for others. This theological attitude will certainly lead him not only to union with God, but also to being part of history as salvation history, taking place at a particular point and time in which he lives and pursues his vocation. Lived in this way, a theological life draws inspiration and power from the Word of God to intrinsically construct (from the human inside) the category of "history" through this form of spirituality.

\subsection{History" as a Category in Liturgical Spirituality}

The Word of God, heard and received in the Holy Spirit, reveals the inner meaning of the actions performed in the liturgy. "Through" these action, the Word leads the faithful into the unfolding mystery of salvation. Two constitutive elements of the liturgy - the sanctification of men by God acting through His Word and through the sacrament of the Eucharist, and the "public worship" given to God by Jesus Christ and His Body (the faithful) - condition each other (cf. SC 7). Christian spirituality has its deep source in the liturgy, because in it the life of God is extended to the faithful directly by Christ, who makes Himself present through the power of the Holy

\footnotetext{
28 Vitali, Esistenza cristiana, 356.

29 Galot, Chi sei tu, o Cristo, 348-351.

30 Benedykt XVI, Jezus z Nazaretu, 14.
} 
Spirit. The way towards this source, and the method of liturgical spirituality, is to know Jesus Christ as revealed in the Eucharistic signs and words.

The category of "history" in liturgical spirituality can be explained in the light of the historical-salvific approach to the liturgy re-adopted by the Second Vatican Council. According to this approach, the sacraments are "moments" in salvation history drawn up in the Old Testament. Fully unveiled in the event of Jesus Christ, they are continued by the Church, guided inherently by the Spirit and the Risen Lord. From this overall historical perspective, the Eucharist must be defined as already being "figuratively" present in the Old Testament, which, in the "fullness of time," emerged as the event that established it, that is, the paschal mystery of Christ. Whereas, in the era of the Church, it continues as a sacrament. Conversely, the whole salvation history is contained in the Eucharist, in the sense that the Eucharist constitutes its summary, showing the path that God takes to the heart of man in Christ.

The Eucharist is the fulfilment of the will of Jesus: "Do this in memory of me," expressed at the time when it was established (1 Cor 11:24). As such, this sacrament actualises His hic et nunc commitment - as a real person - to the salvation of the world: the Passover of Christ and His passage from this world to the Father. Christ's real presence is not achieved by the subjective act of remembrance on the part of a participant in the Eucharist, but by the (objective) realisation of this "memory" (anàmnesis) in the liturgy. Thanks to the Holy Spirit, the salvific event of the past is made real in the present. The Eucharist also makes present the Passover of the Church gathered for the celebration of the paschal mystery of Jesus Christ, and the Passover of each of its individual participants. This mystery encourages them to give thanks and praise to God for the gift of redemption, for the "memory" of the Lord celebrated in a certain place and time, with all of its salvific power given to the Church. Acting not only through the sacrament of the Eucharist, but also through the awareness of the faithful, the Holy Spirit opens up a "space" for listening to the Word of God and its memorisation. Thanks to the Holy Spirit, this space emerges within the community of the faithful and enables their access to the Paschal Gift of Christ. ${ }^{31}$ Thus, salvation is not limited to the past, for "all that Christ is - all that he did and suffered for all men - participates in the divine eternity, and so transcends all times while being made present in them all" (CCC 1085). This "memory" is a biblical category, representative of the Jewish religious circle, while the sacrament is a theological, Christian category, coming from Christ. ${ }^{32}$ It is His gift as a person and the living bread (John 6:48). It is a gift of His grace, "the most precious possession which the Church can have in her journey through history." ${ }^{33}$ Receiving Christ "under the Eucharistic cover" gives rise to the desire of a communicant to see Him "face to face" in eternity.

\footnotetext{
Longcamp, "L’Église," 34.

Ambrosanio, "Eucaristia," 456.

John Paul II, Ecclesia de Eucaristia, 9.
} 
Our love for Him inspires us to engage in the service of our neighbour, in the renewal of the world and in the salvation of mankind. The authentic transformation of the world does not depend on extrinsically observable changes or on the eschatology of conditions ${ }^{34}$ - as if salvation were the result of human achievements or of immanent progress - but on the intrinsic transformation of man in Christ, his metanoia and sanctification.

\subsection{The Category of "History" and the Spirituality of Christian Involvement in the World}

Another field in which the importance of the category of "history" is revealed is the spirituality of Christian involvement in the world. Almost up until the Second Vatican Council, Christians' earthly activity had been regarded as marginal to their spiritual life, or was perceived merely as an opportunity for spiritual merit. Lay Christians, influenced by religious or priestly spirituality and equipped with an elevated image of God, had a low opinion of things created. The most important thing in achieving holiness was to possess a great desire for perfection, to strive for it with enthusiasm and perseverance, and to have the courage to fight adversity, to overcome the tendency to sin, to purge the soul of its worldly attachments and a reject a predilection to enjoy the created world. ${ }^{35}$ Spiritual life was understood in an ahistorical way, detached from the changing and "sinful" world that required a safe distance (fuga mundi).

It was as late as the first half of the twentieth century that the theology of earthly realities began to develop. Many of its guidelines were taken into account by the Fathers of the Second Vatican Council and approved in its resultant documents. The Council portrayed the world as the "theater of man's history" (GS 2), as a place for becoming human and for fulfilling one's Christian vocation. According to the teachings of the Council, man is a being whose potential develops "in" history and "through" active participation in this history. A Christian is aware that "the key, the focal point and the goal" of history is Jesus Christ (GS 10). He is the "key" and "the focal point" because, as the eternal Word, he has granted the whole of creation its ontological structure and, as the Risen Lord, he influences the shaping of world history via the Church. The Church is God's people sent to the world to encourage it to obey the faith and to acknowledge the truth about the relativity of temporal things, which, consequently, calls for their moderate use (1 Cor 7:31). Jesus Christ is also the goal of the entire history of humanity, which, shaped according to God's plan, aims to share in the resurrection of Jesus Christ and to submit the whole world

34 Ratzinger, Eschatologia, 82.

35 Lallement, La dottrina spirituale, 359-361. 
to Him (Eph 3:8-12). ${ }^{36}$ If man believes in the possibility of salvation in Christ, he can already experience it in part in the era of the Church and obtain its fullness "beyond" the limits of history.

Through the salvific work accomplished by Jesus Christ in the "fullness of time," and continued by the power of the Holy Spirit through the Church, the history of the world becomes "salvation history." ${ }^{37}$ This term, derived from 19th-century Protestant theology, especially from Oscar Cullman's ${ }^{38}$ vision of "redemptive history," was introduced in the documents of Vatican II (SC 16; GS 16, 41; DV 2). Eschatology in no way contradicts the historicity of man and the world; instead, it completes it by giving it the highest sense. Gaudium et Spes does not maintain the previously recognised discrepancy between a natural vocation, addressed to all men, and a supernatural vocation, addressed specifically to Christians. Drawing upon its dynamic anthropology, the Constitution states that "the ultimate vocation of man is in fact one, and divine," because there is one Creator of all men and one Saviour for all (GS 22).

The sanctification of the world - a task that is mainly posed for lay Christians consists of uniting all the activities and horizontal relationships established with persons and things, and including them in the vertical relationship with God in Christ by the power of the Holy Spirit. This task also consists of recognising God as God, not only in Himself, but also in His creation, in the voluntary performance of tasks in the family and in social life, so that His name will be hallowed, His kingdom will embrace the world in its present and future history, and His will will be carried out on earth as it is in heaven (Matt 6:9-10). ${ }^{39}$ Two extreme responses to this state of affairs are possible: 1) neglecting our earthly duties towards our neighbour by exclusively directing our lives towards the eschatological goal (Heb 13:14), and 2) immersing ourselves in earthly interests as if they were completely incompatible with religious life, and treating Christian life in terms of the shallow acts of a cult, accompanied by the exercise of certain moral duties (GS 43). In the first case, the Christian does not participate in the building of the earthly community, nor in the creative shaping of history, by which he also neglects being competently prepared for this task. In the second case, he lacks the eschatological awareness necessary to transcend the earthly history, as well as the strength resulting from faith and prayer in order to detach himself from earthly things. Speaking of the complete gratuitousness of eter-

36 Congar, Jésus-Christ notre Médiateur, 209-220.

37 The concept of "salvation history" is a biblical-theological category and signifies God's action towards man in the form of a progressive revelation of Himself to mankind and of His salvific plan being realised in the history of the world - sometimes against the prevailing tendencies. It operates within the categories of promise-fulfilment and in a defined causal sequence: original sin, vocation of the fathers, the Exodus from Egypt, concluding the Covenant, taking possession of the Earth, the Incarnation of the Word, the Cross and Resurrection of Jesus Christ, the institution of the Church, the Second Coming of the Resurrected. Schüngler, "Historia zbawienia," 443-445.

Congar, "Laïc et laïcat," 105. 
nal life, conciliar and post-conciliar moderate eschatologism reminds us of the inescapable duty of transforming the world in the spirit of the new commandment of love (GS 38). Today, responsibility for one's own and others' salvation is inseparably linked with care for the world's welfare, for progress in culture and civilisation, with serving one's neighbour and with making the world more human. ${ }^{40}$ Therefore, all cases of discrimination against man and the violation of his dignity resulting from secularism, moral relativism etc. are a call for Christians to counteract them, and to engage in the work of the moral and spiritual renewal of the earthly order.

\section{4. "History" as a Category in Christian Spiritual Growth}

The explication of spiritual development as one of the research subjects of spirituality theology should take into account the "historical" nature of this development. A true encounter with God takes place in history and develops in history, taking on an increasingly mature form of an interpersonal relationship based on love. It is realised through the Incarnate Word, through which man's redemption and reconciliation with God have been accomplished. The history of Jesus Christ and His act of redemption are of fundamental importance not only for the history of the world and the related salvation history, but also for every person for whom Jesus Christ is the prototype of Christian perfection and the pathway to the realisation of the Christian vocation (GS 22). The beginning of this journey is the implantation into Jesus Christ through baptism, the justification from sin and the gift of new life granted in the community of the Church. Therefore, the category of historicity as a factor of spiritual development should take into account existential Christology, i.e. the life of Jesus Christ known and assimilated through the meditation of the word of God, through prayer. Thus, spiritual growth should be permeated by Christ's paschal mysteries made present and assimilated into the liturgy of the Church. In it, the Risen Lord becomes co-present for the participants of the Eucharist, thanks to which, through faith, it is possible for them to enter into personal contact with Him. The relationship with the crucified and elevated Jesus becomes more and more real and fruitful as man, supported by the Holy Spirit, assimilates the gift that God made of Himself in Jesus Christ, responds to it with love, entrusts himself to God, and opens himself up to the action of that Spirit who intrinsically shapes man in the likeness of the example of Christ. If man willingly cooperates with God's grace and with the gifts and charisms of the Holy Spirit and keeps God's commandments, especially love of God and of one's neighbour, this development leads to the transformation of his whole life and actions.

40 Molari, "La storia nella teologia," 61-64. 
Old asceticism and mysticism focused on the individually understood histories of spiritual lives. They concentrated on the "history of the soul," even though they approached this history in the categories of the Mystical Body of Christ, in which the individual members are one. Contemporary spiritual theology also emphasises the communitarian, ecclesial character of the spiritual life, because man is first enlisted among God's people on a pilgrimage through history, and only then does he grow as an increasingly conscious and responsible Christian. What, then, is the relationship between the two salvation histories, the ecclesial and the individual?

When seen in mutual interdependence, rather than in contradiction, the ecclesial salvation history seems to have formal precedence over the individual history, due to the effectiveness of salvation - the ecclesial history offers the means necessary for an individual salvation history (God's word, the sacraments). The individual salvation history, on the other hand, seems to have existential precedence over the ecclesial history, ${ }^{41}$ since salvation essentially concerns the individual: a person cooperating consciously and freely with God. For this reason, von Balthasar speaks of two sides of the "overall category of 'history" in relation to the continuous stream of the salvific time (kairos): the divine, manifested in the <transcendent>, salvific will of God, which appears in situations with contingent categories that exhibit indications of transcendence to man; and the human, connected with the deepest essence of man, who, in responding to God's call voluntarily chooses what he should choose, and he follows the choice. ${ }^{42}$

The salvific events of universal salvation history, and in particular the event of the redemptive Incarnation, condition the individual salvation history and should become an essential reference point and source of spiritual life. At the same time, the individual history of each faithful follower of Jesus Christ has an influence on the dynamics of the salvation history of the community of believers, taking place in a specific place and time. St. Ignatius Loyola encourages us to take history into account in our meditation on the mystery of the Incarnation. He emphasises that this mystery is realised "for" an individual person, that the fruits of our meditation on it are intended "for" the meditator, ${ }^{43}$ so that the universal dimension of historicity in Ignatian spirituality is connected to the personal dimension. ${ }^{44}$ Contemporary hagiography also requires the biography of the Servant of God to have a historical value, i.e. that his or her life and work be placed in the historical dimension of the world and of the Church, and that it should be presented in chronological order, according to the actual facts and events. ${ }^{45}$ This is contrary to the practice of the past, when the Saints were idealised and historical facts were often overlooked. That practice of

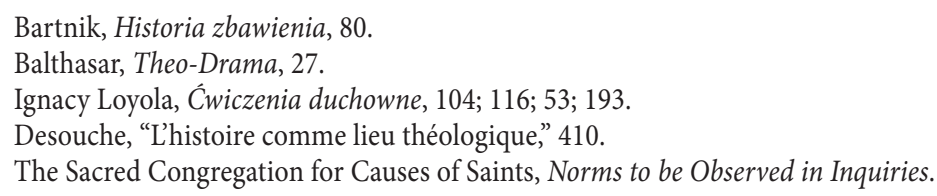


the past failed to show the meeting point and the cross-section of ordinary time with divine time (kairos) in Christian life.

\section{Concluding Remarks}

Our examination of the category of "history" in the four fields of spiritual theology clearly shows not only its usefulness, but also its multiple functions.

As far as biblical spirituality is concerned, this category allows us to unveil the truth of the Gospel and salvation history, which reaches its peak in Jesus Christ. The act of man's redemption is proclaimed in every historical epoch, because it does not belong to the order of knowledge and faith, but preserves its significance for the overall history that acquires its theological meaning, as well as for all people of all times. The transition from the historical nature of the Event of Jesus Christ - from "the hour" in which it actually took place, to the "Divine presence" in which it is sacramentally renewed - is accomplished by the power of the Holy Spirit, who transcends history to enable man to experience the same salvific "the force and power in the word of God" (DV 21) that appeared in illo tempore.

As far as liturgical spirituality is concerned, the category of "history" allows us to return to the moment when the Eucharist is instituted and completed through the passion, death and resurrection of Jesus Christ. Here too, this category is established in every celebration of the Eucharist and, at the same time, it is transcended in its anamnesis, in which, through the action of the Holy Spirit, the historical event of redemption is made present to the faithful in the "today" of the Church, and its salvific fruits are made available to them.

In these first two areas of spiritual theology, the category of "history" contributes to highlighting a proper response to God's gift of salvation as realised in Judaeo-Christian history. This response shapes the attitude of Christian faith, which must be based on the Word of God and the sacraments, and must draw from them the light of truth, spiritual food (Eucharist) and the power of the Spirit.

Including the category of "history" in the next two fields contributes to Christians' - and especially the laity's - activity of shaping earthly history and emphasises a need for individual spiritual and human formation, provided that these categories are related to the two first fields. These latter categories serve to further the practical dimensions of spirituality.

As regards the spirituality of involvement in the world, the category of "history" is useful both for justifying the sense of Christian involvement in the matters of the world and for providing methods for its realisation in history, including its current history, by Catholics called to evangelise the world, to give evangelical witness and to transform the whole worldly reality in accordance with God's thought. This 
commitment to the salvation of others, to the advancement of man and to authentic progress, cultural and civilisation development in various areas of social life is of importance for the eschatological fulfilment of man and the world.

Also in spiritual development, which is the process of following Jesus Christ in a concrete place and time, and in a conditioned way of human interaction with the recurrently displayed grace of the Spirit, in accordance with the divine kairos and leading to an ever-more complete participation in the adopted divine sonship. The category of time and the category of space make it possible to show the historical dynamics of the realisation of man's destiny, of the process of becoming a "new man" in Christ (or not). They also show the natural and supernatural conditions of this process, its connectedness with both secular and ecclesial history, as well as its link with the "centre" or the "climax" of history, i.e. the mystery of redemption actualised in the Eucharist, which is the source of the supernatural life of the Church and of each of the faithful.

\section{Bibliography}

Alberigo, G., "Cristianesimo come storia e teologia confessante,” M.D. Chenu, Le Saulchoir. Una scuola di teologia (Casale Monferrato: Marietti 1982) vii-xxx.

Ambrosanio, A., „Eucaristia,” Nuovo dizionario di teologia (eds. G. Barbaglio - S. Dianich) (Roma: Edizioni Paoline 1982) 447-470.

von Balthasar, H.U., Retour au centre (Paris: Desclée de Brouwer 1998).

von Balthasar, H.U., Theo-Drama. Theological Dramatic Theory. I. Prolegomena (transl. G. Harrison) (San Francisco, CA: Ignatius Press 1988).

Bartnik, Cz.S, Historia ludzka i Chrystus. Szkice z chrześcijańskiej wizji dziejów [Human History and Christ. Sketches from the Christian Vision of History] (Katowice: Księgarnia Św. Jacka 1987).

Bartnik, Cz.S., "Historia zbawienia indywidualna i subiektywna [Individual and Subjective History of Salvation]," Z zagadnień kultury chrześcijańskiej (eds. K. Wojtyła et al.) (Lublin: TN KUL 1973) 77-89.

Bartnik, Cz.S., "Myślenie historyczne w teologii [Historical Thinking in Theology]," Zeszyty Naukowe KUL 19/2 (1976) 91-100.

Bartnik, Cz.S., Teologia historii [History of Salvation] (Lublin: Standruk1999).

Benedykt XVI - Ratzinger, J., Jezus z Nazaretu. I. Od chrztu w Jordanie do Przemienienia [Jesus of Nazareth. I. From the Baptism in the Jordan to the Transfiguration] (Kraków: Wydawnictwo „M” 2007).

Catechism of the Catholic Church, https://www.vatican.va/archive/ENG0015/_P2W.HTM [access: 06.10.2020] (=CCC).

Congar, Y., "L'influence de la société et de l'histoire sur le développement de l'homme chrétien," Nouvelle revue théologique 7 (1974) 673-692.

Congar, Y., Jésus-Christ notre Médiateur, notre Seigneur (Paris: Cerf 1995). 
Congar, Y., "Laïc et laïcat," Dictionnaire de spiritualité ascetique et mystique (eds. M. Villier et al.) (Paris: Beauchesne 1976) IX, 103-106.

Congregation for the Clergy, The Gift of the Priestly Vocation. Ratio Fundamentalis Institutionis Sacerdotalis, http://www.clerus.va/content/dam/clerus/Ratio\%20Fundamentalis/ The\%20Gift \%20of\%20the\%20Priestly\%20Vocation.pdf [access: 6.10.2020].

Desouche, M.Th., "L'histoire comme lieu théologique et fondement de la téologie pastorale," Nouvelle revue théologique 116 (1994) 396-417.

DUDEN Deutsches Universalwörterbuch (eds. G. Drosdowski et al.) (Mannheim - Wien Zürich: Dudenverlag 1983).

Galot, J., Chi sei tu, o Cristo (Firenze: Libreria Editrice Fiorentina 1980).

Góźdź, K., Jezus. Twórca i Spetniciel naszej wiary (Hbr 12,2) [Jesus - Founder and Main Actor of our Faith (Hbr 12:2)] (Lublin: Wydawnictwo KUL 2009).

Goźdź, K., Teologia historii zbawienia wedtug Oscara Cullmanna [History of Salvation's Theology according to Oscar Cullmann] (Lublin: Redakcja Wydawnictw KUL 1996).

Ignacy Loyola, Ćwiczenia duchowne [Spiritual Exercises] (transl. M. Bednarz) (Kraków: Wydawnictwo Apostolstwa Modlitwy 1991).

John Paul II, Apostolic Constitution “Sapientia Christiana," http://w2.vatican.va/content/ john-paul-ii/en/apost_constitutions/documents/hf_jp-ii_apc_15041979_sapientia-christiana.html [access: 6.10.2020].

John Paul II, Encyclical “Ecclesia de Eucaristia, ” http://www.vatican.va/content/john-paul-ii/ en/encyclicals/documents/hf_jp-ii_enc_20030417_eccl-de-euch.html [access: 6.10.2020].

Kowalczyk, M., "Teologia historii [Theology of History]," Encyklopedia katolicka (eds. E. Gigilewicz et al.) (Lublin: TN KUL 2013) XIX, 670-671.

Lallement, L., La dottrina spirituale (Casale Monferrato: Piemme 1984)

de Longcamp, G., "L’Église, communauté de memoire," Nouvelle revue théologique 141 (2019) 22-35.

Macheta, K., "Teologia historyczna [Historical Theology]," Historia i Logos (eds. K. Macheta - K. Góźdź - M. Kowalczyk) (Lublin: [s.n.] 1991) 263-289.

Matanić, A.G., La spiritualità come scienza. Introduzione metodologica allo studio della vita spirituale cristiana (Torino: Edizioni Paoline 1990).

Molari, C., "La storia nella teologia cattolica postconciliare," Il Concilio venti anni dopo. II. L'ingresso della categoria "storia" (ed. E. Cattaneo) (Roma: A.V.E. 1985) 33-68.

de Moulins-Beaufort, E., "Exégèse spirituelle et histoire," Communio 2 (2007) 91-112.

Papieska Rada ds. Krzewienia Nowej Ewangelizacji [The Pontifical Council for the Promotion of the New Evangelisation], Żyć Rokiem Wiary. Program duszpasterski [Living the Year of Faith. Pastoral Program] (transl. M. Masny) (Częstochowa: Edycja Świętego Pawła 2012).

Paul VI, Encyclical “Ecclesiam Suam,” http://w2.vatican.va/content/paul-vi/en/encyclicals/ documents/hf_p-vi_enc_06081964_ecclesiam.html [access: 6.10.2020].

Ratzinger, J., Eschatologia - śmierć i życie wieczne [Eschatology. Death and Eternal Life] (transl. M. Węcławski) (Poznań: Księgarnia Świętego Wojciecha 1984).

Sacred Congregation for Causes of Saints, Norms to be Observed in Inquiries Made by Bishops in the Causes of Saints, https:/www.vatican.va/roman_curia/congregations/csaints/ documents/rc_con_csaints_doc_07021983_norme_en.html [access: 6.10.2020]. 


\section{STANISŁAW T. ZARZYCKI}

Schüngler, P.H., "Historia zbawienia [The History of Salvation]," Praktyczny słownik biblijny (ed. A. Grabner-Haider) (Warszawa: PAX - Wydawnictwo Księży Pallotynów 1994) 443-445.

Second Vatican Council, Constitution on the Sacred Liturgy "Sacrosanctum Concilium," http://www.vatican.va/archive/hist_councils/ii_vatican_council/documents/vat-ii_ const_19631204_sacrosanctum-concilium_en.html [access: 06.10.2020] (=SC).

Second Vatican Council, Decree on Priestly Training “Optatam Totius,” http://www.vatican. va/archive/hist_councils/ii_vatican_council/documents/vat-ii_decree_19651028_optatam-totius_en.html [access: 06.10.2020] $(=O T)$.

Second Vatican Council, Dogmatic Constitution on Divine Revelation "Dei Verbum," http:// www.vatican.va/archive/hist_councils/ii_vatican_council/documents/vat-ii_const_ 19651118_dei-verbum_en.html [access: 06.10.2020] (=DV).

Second Vatican Council, Pastoral Constitution on the Church in the Modern World "Gaudium et Spes, " http://www.vatican.va/archive/hist_councils/ii_vatican_council/documents/vatii_cons_19651207_gaudium-et-spes_en.html [access: 06.10.2020] $(=G S)$.

Secondin, B., "Nozione di spiritualità e alcune recenti collane di storia delle spiritualità," Ricerche Teologiche 1 (1990) 187-205.

Vitali, D., Esistenza cristiana. Fede, speranza e carità (Brescia: Queriniana 2012). 